\author{
УДК 323 (477) \\ https://doi.org/10.34142/24130060.2019.19.2.12
}

\title{
ТРАНСФОРМАЦІЯ ПОЛІТИЧНОГО РЕЖИМУ В УКРАЇНІ ПІСЛЯ ПРЕЗИДЕНТСЬКИХ І ПАРЛАМЕНТСЬКИХ ВИБОРІВ 2019 РОКУ
}

\author{
O.I. Романюк \\ Харківська державна академія культури
}

У статті аналізуються зміни, щзо відбулися в політичній системі Украӥни після президентських та дочасних парламентських виборів 2019 року. На думку автора, вибори 2019 року спричинили прочес трансформації політичного режиму. Електоральна демократія, внаслідок розвитку тенденцій концентрації президентом все більших повноважень $i$ систематичного порушення законодавчих процедур, поступово перетворюється на делегативну демократію - один з різновидів дефектних демократій.

Ключові слова: політичний режим, політичні вибори, електоральна демократія, делегативна демократія, дефектна демократія, Україна.

\section{ТРАНСФОРМАЦИЯ ПОЛИТИЧЕСКОГО РЕЖИМА В УКРАИНЕ ПОСЛЕ ПРЕЗИДЕНТСКИХ И ПАРЛАМЕНТСКИХ ВЫБОРОВ 2019 ГОДА}

\begin{abstract}
А.И. Романюк
В статье анализируются изменения, которые произошли в политической системе Украины после президентских и досрочных парламентских выборов 2019 года. По мнению автора, выборы 2019 года привели к трансформачии политического режима. Электоральная демократия, вследствие развития тенденций концентрации президентом всё больших полномочий и систематического нарушения законодательных процедур, постепенно превращается в делегативную демократию - одну из разновидностей дефектных демократий.

Ключевые слова: политический режим, политические выборы, электоральная демократия, делегативная демократия, дефектная демократия, Украина.

\section{TRANSFORMATION OF THE POLITICAL REGIME IN UKRAINE AFTER THE 2019 PRESIDENTIAL AND PARLIAMENTARY ELECTIONS}

\section{O. Romanyuk}

In this article the author analyzes the changes that occurred in the political system of Ukraine after the 2019 presidential and early parliamentary elections. In his opinion, the 2019 election led to a transformation of the Ukrainian political regime. Electoral democracy, due to the development of tendencies by the president to concentrate more and more powers and systematic violation of legislative procedures, is gradually turning into a delegative democracy, which is one of the varieties of defective democracies.
\end{abstract}

(C) O.I. Романюк, 2019 
The author analyzes the main tendencies in the development of the political situation in Ukraine, which emerged in the presidency of Vladimir Zelensky: monopolization of state power and its concentration in the hands of the president; systematic violations of current legislation; restrictions on local self-government; the offensive on freedom of speech; repression against political opponents. He emphasizes that delegative democracies have two opposite tendencies in their development. The first is the transformation to authoritarianism. Such regimes are considered democracies as long as the presidential power is based on the results of popular expression. However, the concentration of powers carries with it the temptation of administrative and forceful influence in the next election, which, as a result, becomes not free, not competitive, not fair and, therefore, not democratic. The second is the rejection of delegative democracy by society. This is often the case because of mass protests that result from the populist power failing to deliver on its utopian election promises and the associated high hopes of different social strata for the betterment of their lives.

The author believes that both of these options are likely for Ukraine. The possibility of the former is evidenced by the rather questionable dissolution of the Central Election Commission of Ukraine and the creation of a new one, where the majority of the representatives is the creatures of presidential power. The possibility of the second variant is being manifested in mass actions "No capitulation" today.

Key words: political regime, political elections, electoral democracy, delegative democracy, defective democracy, Ukraine.

Постановка проблеми. Президентські (31 березня та 21 квітня 2019 р.) та дочасні парламентські (21 липня 2019 р.) вибори суттєво вплинули на політичну ситуацію в Україні, зумовивши низку негативних тенденцій. Дослідження цих тенденцій $є$ актуальним завданням політичної науки, оскільки їх розвиток здатний призвести до істотних змін у внутрішній та зовнішній політиці Української держави.

Аналіз актуальних досліджень. Хоча дослідження нових тенденцій політичного розвитку України тільки почалося, але вже мається низка публікацій як вітчизняних (Павло Казарін (2019), Сергій Рахманін (2019), Роман Романюк (2019), Марк Савчук (2019), Ярослава Трегубова (2019)), так і зарубіжних (Ян Бейтсон (2019), Андреас Умланд (2019)) авторів, в яких звертається увага на концентрацію в руках президента та його оточення надмірних владних повноважень, порушення законодавчих процедур, згортання свободи преси тощо. Проте це переважно журналістські публікації, в яких фіксуються такі порушення, але бракує достатнього рівня їх аналізу та узагальнення. Серйозні наукові праці, в яких ці тенденції аналізувалися б у контексті змін політичного режиму ще відсутні. 
Мета статті полягає в з’ясуванні того, як політичні вибори 2019 р. вплинули на функціонування політичного режиму в Україні.

\section{Виклад основного матеріалу. Характер попереднього політичного} режсиму. Політичний режим, який був встановлений в Україні внаслідок Революції гідності (Романюк, 2015) і функціонував до виборів 2019 р. був електоральною демократією, оскільки урядова влада грунтувалася на результатах вільних, конкурентних та загальних виборів: президентських (25 травня 2014 р) та парламентських (26 жовтня 2014 р). Формування урядової влади на грунті вільних, конкурентних та загальних виборів $є$ універсальним (мінімальним) критерієм політичної демократії (Diamond, 1996, p. 21). Проте до якості ліберальної демократії він не дотягував, бо ця демократія мала процедурний характер. У політичну практику були втілені основні демократичні процедури, але ще не завершилася розбудова структурних підвалин функціонування політичної демократії: слабкість громадянського суспільства, брак масових демократичних партій та впливових груп політичного тиску, демократична культура ще не стала домінуючим полем політичної культури суспільства. За моніторингом Freedom House «Nations in Transit», у межах якого вирізняються 5 типів політичного режиму (консолідована демократія, напівконсолідована демократія, транзитивне врядування або гібридний режим, напівконсолідований авторитарний режим, консолідований авторитарний режим) політичний режим України визначався як «транзитивне врядування або гібридний режим» (FreedomHouse, 2018a), що не ідентифікувало його ані як демократію, ані як авторитарний режим. Проте за іншим моніторингом Freedom House «Freedom in the Word» Україна була долучена до списку електоральних демократій (FreedomHouse, 2019). Тобто Freedom House ідентифікувала політичний режим в Україні як неконсолідовану демократію. Неконсолідований характер попереднього режиму унаочнювали конфронтаційні відносини, які малися спочатку між революційними силами та силами, що раніше підтримували режим Януковича («Опозиційним блоком»), а потім і всередині революційної 
коаліції (між «БПП Солідарністю» $\mathrm{i}$ «Народним фронтом», з одного боку, та «Батьківщиною», «Самопоміччю» і Радикальною партією Олега Ляшка, 3 іншого).

Причини поразки попередньої влади. Сформована в Україні після Революції гідності влада зазнала поразки в 2019 р. внаслідок глибокого розчарування населення України в результатах ії діяльності, що було спричинене низкою чинників.

По-перше, російською агресією проти України, яка була спричинена тим, що Революція гідності скинула проросійський режим Януковича. Російська агресія своїм наслідком мала окупацію Криму та значної частини Донбасу (44 тис. км² - 13,7\% території України). Внаслідок агресії Україна втратила понад $16 \%$ свого ВВП (УНІАН, 2017). Російська агресія змусила Україну значно збільшити свій військовий бюджет (з 15,3 млрд грн. у 2013 p. (Finance.ua., 2012) до 209,7 млрд грн.на 2019 р. (Радіо Свобода., 2018)). Природно, що все це вкрай негативно відбилося на соціально-економічної ситуації в країні та, внаслідок цього, на політичних преференціях громадян.

По-друге, початком проведення постреволюційною владою масштабних реформ в галузі економіки та інших сферах суспільного життя. Реформи завжди являють собою досить болісне явище, бо старі структури демонтуються, а нові треба ще налагодити. Особливо негативний плив на суспільну свідомість справили ринкові реформи в енергетичній сфері, які привели до істотного зростання житлово-комунальних платежів. За даними Організації економічного співробітництва та розвитку, витрати українців на оплату житлово-комунального господарства в 2018 р. становили 39\% їх доходів (Савенко, 2018).

По-третє, інформаційною війною Росії проти нової влади. Напередодні виборів російська пропаганда посилила розповсюдження різних фейків, що дискредитували президента Порошенка та уряд. Вони поширювалися всередині країни проросійськими симпатиками та олігархічними кланами. Поширенню сприяло те, що абсолютна більшість українських засобів масової 
інформації продовжували перебувати в руках олігархів. Головною темою інформаційних атак проти революційної влади було «небувале зростання корупції». Проте авторитетні міжнародні структури, що відслідковували проблему корупції в усьому світі, такого не фіксували. Так за даними моніторингу «Nation in Transit» рівень корупції в Україні за період 2014-2018 pp. не тільки не збільшився, але знизився на 0,5 пункти (з 6,25 до 5,75$)$ за семибальною шкалою (FreedomHouse, 2018b).

Внаслідок цих обставин, колишній президент України Петро Порошенко зазнав на президентських виборах 2019 р. поразки від Володимира Зеленського, який напередодні виборів раптом 3'явився в політичному процесі як Deus ex machina. Не зважаючи на те, що Зеленський не мав чіткої не то що програми, але й позиції (його «передвиборча програма» являла собою набір суперечливих популістських гасел), фахової команди (його виборча команда складалася в основному 3 піарщиків), підтримки потужної політичної партії (партія «Слуга народу», яка висунула його кандидатуру, тільки почала формуватися), він здобув підтримку в 1-му турі 30,24 \% виборців, які взяли участь у голосуванні, у 2-му - 72,22 \%. Це народило ейфорію про «небувалу підтримку» Зеленського. Насправді «небувалої підтримки» не було. Кращі за Зеленського результати на президентських виборах одержали: Леонід Кравчук в 1991 р. - 61,59 \% в 1-му турі та Петро Порошенко в 2014 p - 54,70 \% також у 1-му турі. Другий тур в обох випадках відповідно Закону України «Про вибори Президента України» не проводився (Законодавство України, 2019а, ст. 84, п. 3).

Тенденції діяльності нової влади. Перші кроки Зеленського на посту Президента України ознаменувалися його конфронтацією 3 Верховною Радою (ВР). Розуміючи ситуативність своєї перемоги і те, що ситуативні голоси можуть швидко розтанути, Зеленський не став чекати чергових парламентських виборів, які мали відбутися 27 жовтня 2019 р., і в інавгураційній промові оголосив про дострокове припинення повноважень ВР. Наступного дня він підписав з цього приводу Указ, яким призначив 
позачергові вибори до ВР України на 21 липня 2019 р. (President.gov., 2019b), аргументуючи це тим, що в коаліції депутатських фракцій ВР «Свропейська Україна («БПП- Солідарність» та «Народний фронт») немає абсолютної більшості народних депутатів, що передбачає Конституція України (President.gov., 2019а, ст. 83). У інавгураційні промові Зеленський також попросив уряд піти у відставку, хоча за Конституцією він такого права не мав (President.gov., 2019a, ст. 115). Не дивлячись на те, що прем'єр-міністр Володимир Гройсман все ж таки написав заяву про відставку, що автоматично тягнуло за собою відставку усього уряду, ВР іï не прийняла й також відмовилась затверджувати президентські кандидатури на посади міністра закордонних справ та міністра оборони. Не бажаючи дочасно складати свої повноваження, 62 народні депутати зробили подання до Конституційного Суду України (КСУ) щодо конституційності указу про розпуск ВР, оскільки факт відсутності в коаліції «Європейська Україна» абсолютної більшості народних депутатів юридично не встановлений. Розглянувши подання, КСУ ухвалив «соломонове рішення» - оскільки неможна юридично довести як те, що в ВР немає коаліції депутатських фракцій, так і те що вона існує, то хай конфлікт між президентом i парламентом розв'язує народ на позачергових парламентських виборах (Конституційний Суд України, 2019).

21 липня 2019 р. відбулися позачергові вибори ВР, в яких вперше взяло участь менше 50 \% виборців - 49,84 \%. За їх результатами вперше абсолютну більшість місць (254 з 424-х) отримала одна партія - пропрезидентська «Слуга народу». Після парламентських виборів негативні тенденції в політичній системі України значно посилилися. До таких належать:

1. Монополізаиія державної влади та ї концентрація руках президента. Отримавши абсолютну більшість місць у парламенті, «Слуга народу» захопила все керівництво ВР: посади голови та першого його заступника, а також посади голів 19-ти з 23-х іiі комітетів. Парламентська більшість сформувала новий уряд, проте «цього разу усі без винятку рішення 
щодо складу уряду ухвалював президент» (Романюк, Р., 2019). Як зауважує Андрес Умланд: «Результатом українських виборів стало зосередження всієї виконавчої та здебільшого законодавчої влади в руках однієї партії » (Umland, 2019).

Монополізація влади унаочнилася також у дочасному розпуску Центральної Виборчої Комісії (ЦВК), яка була створена попереднім складом ВР 6 жовтня 2018 р. і провела президентські та парламентські вибори 2019 р. За висновками вітчизняних та зарубіжних спостерігачів та фахівців в галузі виборчого права, ці вибори були самими чесними та прозорими за всю історію українських виборів. Відповідно Закону України «Про Центральну Виборчу Комісію» строк повноважень членів комісії становить 7 років (Законодавство України, 2004, ст. 6, п. 8) і жодних розумних аргументів щодо iii розпуску не було. Проте новий склад ВР за ініціативою офісу президента 13 вересня 2019 р. ухвалив постанову «Про дострокове припинення повноважень всього складу Центральної виборчої комісії», а 4 жовтня затвердив нову ЦВК, в якій їі головою та секретарем, а також 12 членами 317 стали висуванці партії «Слуга народу» (Укрінформ, 2019).

Під загрозою опинилася й незалежність судової влади. 29 серпня президентом був внесений у ВР як невідкладний проект закону «Про внесення змін до деяких законів України щодо діяльності органів суддівського врядування», яким передбачалося скорочення складу Верховного Суду з 200 до 100 суддів, зміни в правилах відбору членів Вищої кваліфікаційної комісії суддів України та повне перезавантаження цього органу, створення при Вищій раді правосуддя комісії доброчесності та етики, а також розширення списку посад судової влади, на які поширюється люстрація. Не дивлячись на серйозні зауваження щодо цього законопроекту 3 боку Голови Верховного Суду України, керівників Ради Свропи та делегації ЄС в Україні, відсутності висновку Венеційської комісії, опору з боку 4-х фракцій ВР, 16 жовтня він був ухвалений голосами 236-ти народних депутатів (217 голосів депутатів фракції «Слуга народу» та 17 голосів 
позафракційних) (Новинарня, 2019). Характеризуючи недоліки цього закону, Генеральний секретар Ради Свропи Марія Пейчіновіч-Бурич, заявила, що він запроваджує широкомасштабні зміни, які «можуть призвести до значних наслідків для незалежності судової системи, в особливості, щодо статусу, кваліфікаційних вимог до суддів та пов'язаних 3 цим процедур» (Свропейська правда, 2019).

2. Систематичні порушення чинного законодавства, що унаочнюе вебсайт «Ze.live», який 24 травня 2019 р. включив «лічильник» порушень законодавства з боку президента Зеленського. За перших 114 днів каденції Зеленського було зафіксовано 42 таких порушення (Ze.live, 2019). Яскравим прикладом порушень $є$ призначення на державні посади: Андрія Богдана головою адміністрації Президента, всупереч закону «Про очищення влади» (Законодавство України, 2014, ст. 3), бо Богдан працював заступником міністра кабінету міністрів в уряді Миколи Азарова; Руслана Хомчака на посаду начальника Генштабу ЗСУ без подання міністра оборони, що вимагає Положення «Про Генеральний штаб Збройних Сил України» (Законодавство України, 2019с, п. 9); Івана Баканова, який не склав з себе повноважень голови партії «Слуга народу», першим заступником голови СБУ, що заборонено законом «Про Службу безпеки України» (Законодавство України, 2019b, ст. 6).

3. Обмеження місиевого самоврядування. 24 вересня 2019 р. група депутатів на чолі $з$ представником фракції «Слуга народу» Олександром Ткаченком подали до парламенту законопроект «Про місто Київ - столицю України», де пропонується знов розділити посади Київського міського голови та голови Київської міської державної адміністрації та передбачається, що формування структур виконавчої влади в столиці, все поточне управління містом та діяльність, що пов'язана з розходами міського бюджету, буде зосереджена в руках голови КМДА, якого буде призначати Президент за поданням Кабінету Міністрів. 
4. Наступ на свободу слова. За рішеннями Печерського суду Києва в липні 2019 р. було заблоковано проукраїнську блогерську платформу «Enigma», Генеральна прокуратура отримала доступ до приватної інформації 3 телефонів журналістки та головної редакторки програми «Схеми» Наталії Седлецької та журналістки «Нового Времени» Христини Бердинських. У межах провадження Державного бюро розслідувань щодо можливого ухилення від сплати податків під час продажу телеканалу «Прямий», який посідає опозиційну позицію до теперішньої влади, відбуваються спроби його рейдерського захоплення.

5. Репресії проти політичних опонентів. За зверненнями колишнього заступника глави Адміністрації Президента часів Януковича Андрія Портнова, який $є$ наближеною людиною до нинішнього глави Офісу Президента Андрія Богдана, правоохоронними органами були відкриті досить сумнівні карні справи стосовно попереднього Президента України Петра Порошенка, попереднього Голови Верховної Ради Андрія Парубія. За двічі закритим кримінальним впровадженням, 7 жовтня 2019 р. було заарештовано, без можливості внесення застави, одного 3 керівників «Майдану гідності» колишнього народного депутата від «Народного фронту» Сергія Пашинського. На думку авторитетного політичного експерта Андрія Смолія: «Арешт Пашинського $\epsilon$ початком переслідувань політичних опонентів 3 боку влади. Це ще раз показує, що наразі судова та правоохоронна системи в Україні є залежними й виконують замовлення для знищення політичних опонентів чинної влади» (Прямий.uа., 2019).

Який режим формується в Украӥні. Виходячи з викладеного вище, політичний режим, що формується в Україні слід ідентифікувати як делегативну демократію. Концепт делегативної демократії належить аргентинському політологу Гілльєрмо О’Доннеллу, якій під такою розумів режими, котрі «грунтуються на посилці, що перемога на президентських виборах дає переможцю право керувати країною за своїм розсудом, при цьому він обмежений лише обставинами існуючих владних відносин та 
визначеним Конституцією терміном його повноважень» (1994, p. 59). О’Доннелл акцентує увагу на таких рисах делегативної демократії: після виборів очікується, що «виборці/делегатори стануть пасивною публікою, яка проте підтримуватиме все, що робить президент» (1994, р. 60); президентське врядування «може бути несхожим 3 обіцянками його передвиборної кампанії» (ibid); перемога президента на виборах зумовлюється «його обіцянками врятувати країну без особливого збитку для кожного з громадян, але незабаром його політика, що спричиняє значні збитки для багатьох верств населення, ставить на кін долю його врядування» (О’Donnell 1994, p 66);

Німецькі політологи Вольфганг Меркель, Аврель Круассан, ГансЮрген Пугле, Петер Тері віднесли делегативні демократії до одного 3 різновидів дефектних демократій, під якими розуміються «системи врядування, що характеризуються наявністю значимого та дієвого виборчого режиму, який регулює доступ до влади (вільні, таємні, рівні та загальні вибори), проте вони мають суттєві функціональні обмеження інститутів, що забезпечують політичну участь та захист базових політичних прав i громадянських свобод, а також неефективний горизонтальний контроль над демократично легітимною владою» (Merkel and Croissant, 2000, s. 4 fff). У концепції дефектних демократій термін делегативної демократії набув іншої конотації. У той час як поняття «делегувння» О’Доннелла, характеризує відносини між виборцями та президентом (вертикальне делегування), використання цього терміну в концепції дефектної демократії акцентує увагу на відносинах між урядом, парламентом і судовою системою (горизонтальне делегування) (Croissant and Thiery, 2000, s. $28 \mathrm{fff}$ ). Головними вадами делегативних демократій на думку фундаторів цієї концепції $є$ те, що: підривається система стримувань та противаг, котра необхідна функціонуючим демократіям для підтримання збалансованого політичного представництва; виконавча влада домінує над законодавчою, судові органи лише обмеженою мірою здійснюють контроль за виконавчими структурами; 
уряд (як правило на чолі 3 харизматичним президентом) оминаючи парламент діє 3 порушенням конституції та, часто, регулює суспільні відносини за допомогою декретів; не санкціоновані народом особи наділяються повнотою владних повноважень (Croissant and Thiery, 2000, s. $28 ; 29$, p. 50; 33, p. 12).

Висновки і перспективи подальших досліджень. У 2019 році відбулися суттєві зміни в функціонуванні політичного режиму в Україні. Після президентських та, особливо, дочасних парламентських виборів електоральна демократія змінилася режимом делегативної демократії, в межах якого за систематичного порушення процедур чинного законодавства владні повноваження все більше концентруються в руках президента та його оточення, встановлений пріоритет виконавчої влади над законодавчою та судовою, руйнується система стримувань та противаг.

Делегативні демократії мають дві протилежні тенденції свого розвитку. Перша - трансформація до авторитаризму. Такі режими вважаються демократіями доти, поки президентська влада грунтується на результатах народного волевиявлення. Проте концентрація владних повноважень несе в собі спокусу адміністративного та силового впливу на наступні вибори, котрі через це стають не вільними, не конкурентними, не чесними та, як узагальнення, не демократичними. Друга - відторгнення делегативної демократії суспільством. Таке часто відбувається завдяки акціям масового протесту, які виникають внаслідок того, що популістська влада виявляється неспроможною реалізувати свої утопічні передвиборчі обіцянки та пов'язані 3 ними великі надії різних соціальних верств на покращання свого життя. Це тягне за собою делегітимізацію режиму, втрату президентом своєї харизми та його усунення від влади.

Для України є імовірними обидва ці варіанти. Про можливість першого свідчить досить сумнівний розпуск Центральної виборчої комісії України та створення нової, де абсолютну більшість мають представники президентської сили. Можливість другого сьогодні унаочнюються в масових акціях «Ні 
капітуляції», що виникли внаслідок підписання представником Президента Леонідом Кучмою на засіданні трьохсторонньої контактної групи 3 урегулювання ситуації на Донбасі так званої «формули Штайнмайера», котра несе в собі загрозу територіальної цілісності України та ії національній безпеці. Дослідження тенденцій розвитку політичної ситуації в Україні є актуальним завданням політичної науки.

\section{ЛIТЕРАТУРА}

1. Голос України, 2019. Постанова Верховної Ради України № 90-IX «Про дострокове припинення повноважень всього складу Центральної виборчої комісї̈». [online] (Останне http://www.golos.com.ua/article/321737 [Дата звернення 14 Жовтень 2019].

2. Свропейська правда, 2019. Генсек Ради Європи розкритикувала проєкт судової реформи Зеленського. [online] (Останнє оновлення 03 Жовтень 2019) Доступно: https://www.eurointegration.com.ua/news/2019/10/3/7101490/ [Дата звернення 12 Жовтень 2019].

3. Законодавство України, 2004. Закон України «Про Центральну Виборчу Комісію». [online] Доступно: https://zakon.rada.gov.ua/laws/show/1932-15 [Дата звернення 14 Жовтень 2019].

4. Законодавство України, 2014. Закон України «Про очищення влади». [online] Доступно: https://zakon.rada.gov.ua/laws/show/1682-18 [Дата звернення 14 Жовтень 2019].

5. Законодавство України, 2019а. Закон України «Про вибори Президента України». [online] Доступно: https://zakon.rada.gov.ua/laws/show/474-14 [Дата звернення 14 Жовтень 2019].

6. Законодавство України, 2019b. Закон України «Про Службу безпеки України». [online] Доступно: https://zakon.rada.gov.ua/laws/show/2229-12 [Дата звернення 14 Жовтень 2019].

7. Законодавство України, 2019с. Положення «Про Генеральний штаб Збройних Сил України». [online] Доступно: https://zakon.rada.gov.ua/laws/show/23/2019?lang=uk [Дата звернення 14 Жовтень 2019]

8. Казарин, П., 2019. Горе победителям. [online] (Останнє оновлення 28 Июль 2019) Доступно: https://nv.ua/opinion/gore-pobeditelyam-chto-zhdet-zelenskogo-novostiukrainy-50034345.html [Дата звернення 14 Жовтень 2019].

9. Конституційний Суд України, 2019. Рімення Конституційного Суду України у справі за конституційним поданням 62 народних депутатів Украӥни щзодо відповідності Конституції Украӥни (конституційності) Указу Президента Украӥни «Про дострокове припинення повноважень Верховної Ради України та призначення позачергових виборів». [online] Доступно: http://ccu.gov.ua/docs/2770 [Дата звернення 18 Жовтень 2019].

10. Новинарня, 2019. Рада ухвалила судову реформу Зеленського: про щзо вона і чому опозиція проти. [online] (Останне оновлення 17 Жовтень 2019) Доступно: 
https://novynarnia.com/2019/10/17/rada-uhvalila-sudovu-reformu-zelenskogo-pro-shhovona-i-chomu-opozitsiya-proti/ [Дата звернення 18 Жовтень 2019].

11. Прямий.uа., 2019. Арешт Пашинського - це початок політичних переслідувань опозиціiі. [online] (Останнє оновлення 8 Жовтень 2019) Доступно: https://prm.ua/aresht-pashinskogo-tse-pochatok-politichnih-peresliduvan-opozitsiyismoliy/ [Дата звернення 10 Жовтень 2019].

12. Радіо Свобода., 2018. Держбюджет - 2019 в цифрах. [online] (Останнє оновлення 07 Грудень 2018) Доступно: https://www.radiosvoboda.org/a/29641778.html [Дата звернення 12 Жовтень 2019].

13. Рахманін, С., 2019. Гра у швидкі «шашечки». Дзеркало тижня, 25-31 Трав.

14. Романюк, О., 2015. Революція гідності. В: М. П. Требін, ред. Політологічний енциклопедичний словник. Харків: Право. с. 610-612.

15. Романюк, Р., 2019. Президентсько-Богданська республіка. Як Зеленський концентрує владу. [online] (Останне оновлення 23 Вересень 2019) Доступно: https://www.pravda.com.ua/articles/2019/09/23/7227031/ [Дата звернення 12 Жовтень 2019].

16. Савенко, С., 2018. Тарифи-2018: скільки і кому доведеться віддавати за комуналку? [online] (Останнє оновлення 22 Січень 2018) Доступно: https://news.finance.ua/ua/news/-/418925/taryfy-2018-skilky-i-komu-dovedetsyaviddavaty-za-komunalku [Дата звернення 12 Жовтень 2019].

17. Савчук, М., 2019. 60 дней Зеленского. [online] Доступно: https://site.ua/mark.savchuk/21428-60-dney-zelenskogo/?fbclid=IwAR0oSvZ1z5Z6VSTNTLp-yzJiDHo05iGv7zUDQRe-JaB0AhJXFDHcXH7DcE [Дата звернення 12 Жовтень 2019].

18. Трегубова, Я., 2019. 100 днів Зеленського: щзо встиг зробити президент. [online] (Останнє оновлення 27 Серпень 2019) Доступно: https://www.radiosvoboda.org/a/stodniv-zelenskogo/30130851.html [Дата звернення 10 Жовтень 2019].

19. Укрінформ, 2019. Рада призначила новий склад ЦВК. [online] (Останнє оновлення 04 Жовтень 2019) Доступно: https://www.ukrinform.ua/rubric-polytics/2793051-radapriznacila-novij-sklad-cvk.html [Дата звернення 14 Жовтень 2019].

20. УНІАН, 2017. Гройсман: Україна через агресію Росії втратила понад $16 \%$ ВВП. [online] (Останне оновлення 10 Липень 2017) Доступно: https://www.unian.ua/economics/finance/2020379-ukrajina-cherez-agresiyu-rosiji-vtratilaponad-16-vvp-groysman.html [Дата звернення 12 Жовтень 2019].

21. Finance.ua., 2012. Військові видатки України в 2013 році збільшені на 1,15\% Мінфін. [online] (Останне оновлення 13 Грудень 2019) Доступно: https://news.finance.ua/ua/news/-/293024/vijskovi-vydatky-ukrayiny-v-2013-rotsizbilsheni-na-1-15-minfin [Дата звернення 10 Жовтень 2019]

22. President.gov., 2019а. Конституція України. Із змінами, внесеними Законами України від 8 грудня 2004 року N 2222-IV, від 1 лютого 2011 року N 2952-VI, від 19 вересня 2013 року N 586-VII, від 21 лютого 2014 року N 742-VII, від 2 червня 2016 року N 1401-VIII, від 07 лютого 2019 року, N 2680-VII. [online] Доступно: https://www.president.gov.ua/documents/constitution [Дата звернення 14 Жовтень 2019]. 
23. President.gov., 2019b. Указ Президента України №303/2019 Про дострокове припинення повноважень Верховної Ради України та призначення позачергових виборів. [online] (Останне оновлення 21 Травень 2019) Доступно: https://www.president.gov.ua/documents/3032019-27121 [Дата звернення 12 Жовтень 2019].

24. Ze.live, 2019. Архів. [online] Доступно: https://ze.live/archive/ [Дата звернення 10 Жовтень 2019].

25. Bateson, I., 2019. Volodymyr Zelensky Plays Himself. The president of Ukraine is easily found on social media, but rarely submits to journalists' questioning. [online] (Last updated 25 September 2019) Available at: https://www.theatlantic.com/international/archive/2019/09/ukraine-volodymyr-zelenskyubiquity-transparency/598774/ [Accessed 14 October 2019].

26. Croissant, A. and Thiery P., 2000. Von defekten und anderen Demokratien. WeltTrends, 29 (Winter), s. 9-32.

27. Diamond, L., 1996. Is the Third Wave of Democratization Over? Journal of Democracy, 7 (3), pp. 20-37.

28. FreedomHouse, 2018a. Nations in Transit. [online] Available at: https://freedomhouse.org/report-types/nations-transit [Accessed 10 October 2019].

29. FreedomHouse, 2018b. Ukraine Country Profile. Nations in Transit. [online] Available at: https://freedomhouse.org/report/nations-transit/2018/ukraine

30. FreedomHouse, 2019 Freedom in the World. [online] Available at: https://freedomhouse.org/report-types/freedom-world [Accessed 14 October 2019].

31. Merkel, W. and Croissant A., 2000. Formale Institution und informale Regein in defecten Democratien. Politische Vierteljahresschrift, (1) 41, s 3-30.

32. Merkel, W., 2004. Embedded and Defective Democracies. Democratization, 5 (11), pp. 33-58.

33. O’Donnell, G. A., 1994. Delegative Democracy. Journal of Democracy, 1 (5), pp. 55-69.

34. Puhle, H.-J., 2005. Democratic Consolidation and «Defective Democracies». [online] Facultad de Derecho Universidad Autonoma de Madrid. Available at: www.uam.es/centros/derecho/cpolitica/papers.htm [Accessed 10 October 2019].

35. Umland, A., 2019. Ukraine: «Le président Zelensky face à la "continuité comportementale de l'élite"». [online] (Last updated 8 August 2019) Available at: https://www.lemonde.fr/idees/article/2019/08/08/ukraine-le-president-zelensky-face-a-lacontinuite-comportementale-de-1-elite_5497575_3232.html.

\section{Інформація про автора}

Романюк Олександр Іванович- доктор політичних наук, професор, професор кафедри філософії та політології Харківської державної академії культури; e-mail: olexromanyuk@ukr.net; ORCID: http://orcid.org/0000-0002-8756-9018.

Стаття надійшла до редакції: 12.11.2019 р. $\quad$ Прийнята до друку: 27.11.2019 p. 